\title{
Heterogeneous Effects of the Belt and Road Initiative on Energy Efficiency in Participating Countries
}

\author{
Yan $\mathrm{Wu}^{1}$, Cong $\mathrm{Hu}^{2, *}$ and Xunpeng $\mathrm{Shi}^{3}{ }^{3}$ \\ 1 School of Economics, Beijing Technology and Business University, Beijing 100048, China; wuyan@btbu.edu.cn \\ 2 School of International Development and Cooperation, University of International Business and Economics, \\ Beijing 100029, China \\ 3 Australia-China Relations Institute, University of Technology Sydney, Sydney, NSW 2007, Australia; \\ Xunpeng.Shi@uts.edu.au \\ * Correspondence: bshida@126.com
}

Citation: Wu, Y.; Hu, C.; Shi, X. Heterogeneous Effects of the Belt and Road Initiative on Energy Efficiency in Participating Countries. Energies 2021, 14, 5594. https://doi.org/ $10.3390 /$ en14185594

Academic Editor: Pablo del Río

Received: 11 August 2021

Accepted: 31 August 2021

Published: 7 September 2021

Publisher's Note: MDPI stays neutral with regard to jurisdictional claims in published maps and institutional affiliations.

Copyright: (c) 2021 by the authors. Licensee MDPI, Basel, Switzerland. This article is an open access article distributed under the terms and conditions of the Creative Commons Attribution (CC BY) license (https:// creativecommons.org/licenses/by/ $4.0 /)$.

\begin{abstract}
The Belt and Road investment involves a large number of renewable energy projects, but whether the energy efficiency is linked to the Belt and Road Initiative (BRI) cooperation has yet to be established in the literature. This research attempts to close this gap by looking at how the BRI affects the energy efficiency of participating nations after the fact through a counterfactual analysis. Based on the Difference-in-Difference-in-Difference (DDD) and quantile DID methods for the panel dataset covering 178 nations and areas for the period of 2002 to 2018, we explored the impacts of BRI on energy efficiency vary by different energy efficiency quantiles, resource endowments, and income levels. First, the positive effects of BRI are significant in medium-and high-energy efficiency quantiles but are not significant in low-energy efficiency quantiles for up to 30\%. Second, the BRI tends to increase more energy efficiencies in resource-rich BRI countries than those in resource-poor BRI countries. Third, the BRI tends to increase more energy efficiencies in low-income BRI countries than those in high-income BRI countries. The findings can assist BRI countries in improving energy efficiency and sustainable development capacity under the initiative, thus resolving the increasing anxieties in climate change and environmental pollution in this area.
\end{abstract}

Keywords: energy efficiency; difference-in-difference-in-difference; quantile difference-in-difference; Belt and Road Initiative; China

\section{Introduction}

The Belt and Road Initiative (BRI) is the first initiative that has global trade, investment, and exchange impacts based on international cooperation among most developing countries in the world. Since the BRI was proposed in 2013, green has been the undertone of the initiative. The green BRI aims to reduce environmental pollution and carbon emissions while promoting economic development in BRI countries. It includes the construction of clean energy infrastructure, green credit, and cooperation in science, technology, and education, which may promote technological progress, industrial upgrading and thus energy efficiency in BRI countries. At the same time, some criticism has been heard. China's investment in BRI countries may involve the transfer of high-polluting and energy-intensive production capacity to these countries, while China's investment in fossil fuels, such as thermal power and oil and gas pipelines, also makes the local economy more dependent on fossil fuels production.

After proposing the BRI, China's investment in the energy sector of BRI countries focuses on clean energy production with comparative advantages such as hydropower, wind power and solar cell factories, as well as the efficiency of extraction and transportation of traditional energy, increasing BRI countries' income while avoiding waste of fossil energy use and improving the energy efficiency. For example, energy projects account for $75 \%$ of China's investment in Pakistan. Among them, the Karot hydropower project is the 
first large-scale energy project under the BRI, which won the 2017 Infrastructure Journal Global Best Financing Award for the hydropower project in the Asia-Pacific area. In addition, Ethiopia's Adama wind power plant is the first one outside of China to utilize Chinese rules and techniques and provides more than 20 percent of the Ethiopian capital's electricity needs. Moreover, with the fast development of China's photovoltaic device in both production capacity and technology, a solar cell and module production plant in Penang Malaysia was invested in by Chinese Jinko Solar in 2015. By the end of 2018, Jinko solar had built seven plants in Malaysia with a capacity of $3500 \mathrm{MW}$ for cells and $3000 \mathrm{MW}$ for modules, effectively boosting the proportion of clean energy generation in Malaysia.

On the other hand, there has been an increase in global concern about climate change and pollution in recent years, particularly in developing nations, which is closely related to energy efficiency. Due to the need for economic development and unavoidable energy consumption, developing countries should improve technology and upgrade industries to increase energy efficiency for reducing pollution and developing in a low-carbon model. However, up to this point in time, the energy efficiency of the BRI nations has been relatively poor. The BRI nations' average energy efficiency in 2018 was 30 percent lower than that of OECD countries and roughly 50 percent lower than the world average. A significant component of sustainable development in BRI nations is improving energy efficiency. It is also a key countermeasure to combat climate change and environmental pollution concerns in international cooperation contexts.

However, the impact of the BRI on the energy efficiency of participating countries is currently controversial. Some studies claimed that BRI members will see a decline in their energy efficiency due to the increase of economic activity, particularly infrastructure construction and natural resource development [1-3]. According to other research, BRI collaboration with China would increase the energy efficiency of BRI nations as well as their ability to achieve sustainable growth in the long term [4-6]. To this end, this study will investigate whether the BRI affects the energy efficiency of participating nations positively or negatively to address this vacuum in knowledge. As of 2020,140 countries have formally joined the BRI, providing a quasi-natural experiment for evaluating the effects of this event on the energy efficiency of BRI nations.

In this study, the following contributions have been made based on a counterfactual analysis. (a) This analysis empirically assesses the impact of the BRI on energy efficiency based on the Difference-in-Difference (DID) method and various tests have been made for the robustness of the results. (b) It explores the impact of BRI on energy efficiency varies by different energy efficiency quantile levels, showing that the effects are significant in the medium- and high-energy efficiency quantile levels but are not significant in low quantile levels. (c) It investigates how the impact of BRI on energy efficiency varies by different BRI country groups in resource endowments and income levels. The BRI tends to increase more energy efficiencies in resource-rich and low-income BRI countries than those in other BRI countries. Such heterogeneous effects can help to make customized policy implications based on different types of countries under the context of BRI.

The structure of this research is as follows. A mechanism analysis and a literature review on the relationship between BRI and energy efficiency are presented in Section 2. A regression model based on the DID approach is estimated for energy efficiency in Section 3, and the methods as well as the data source are also illustrated in this section. According to the DID, quantile DID, and Difference-in-Difference-in-Difference (DDD) methods, in Section 4, the study finds that the BRI's influence on energy efficiency varies depending on different energy efficiency quantile levels, resource endowments and income levels. Section 5 concludes the research and gives the policy implication.

\section{The Belt and Road Initiative and Energy Efficiency: Mechanism and Literature}

\subsection{The Belt and Road Initiative's Effect on Energy Efficiency}

Many improvements related to energy efficiency are possible, such as economic growth, technological spillovers, and industrial transformation, as a result of China and 
BRI countries working together to implement BRI projects across the world. Under the BRI, China's outward foreign investment, export and import, and international exchange with other BRI countries have grown rapidly since 2013. Consequently, we will analyze the relationship between the BRI and energy efficiency based on the above three aspects.

Generally speaking, it is challenging for developing countries to fulfill their energysaving and emission-reduction potentials owing to a lack of finances as well as efficient solutions, and the cost of achieving energy saving and emission reduction may be higher than that of developed countries. Most developing countries still rely on coal for power generation. For example, China generated $49 \%$ of its electricity from coal in 2020, while India generated 58\% [7], which may be due to the fact that coal is cheap and available, the plants can be erected quickly, and they are familiar with the technologies [8], so as to satisfy their fast development. Since 2011, greenhouse gas (GHG) concentrations have continued to increase in the atmosphere, reaching annual averages of $410 \mathrm{ppm}$ for $\mathrm{CO}_{2}, 1866 \mathrm{ppb}$ for $\mathrm{CH}_{4}$, and $332 \mathrm{ppb}$ for $\mathrm{N}_{2} \mathrm{O}$ in 2019 [9]. The land and the ocean have taken up a nearconstant proportion (globally, about $56 \%$ per year) of $\mathrm{CO}_{2}$ emissions from human activities over the past six decades [9]. The governments of most developed countries attach great importance to emission reduction and set specific emission reduction targets. However, most BRI countries are developing countries, and they need more cooperation, especially capital and technology support for increasing the share of renewable energy and improving their energy efficiencies for reducing $\mathrm{CO}_{2}$ and dealing with climate change together.

In terms of the impact of China's outward foreign investment, after proposing the BRI, China's investments in the energy sector of BRI countries focused on clean energy with comparative advantages such as hydropower stations, wind power stations, and solar cell factories. These clean energy infrastructures have reduced the use of fossil fuels and helped BRI countries' economic growth. Therefore, the increase of fossil energy consumption is relatively lower compared with the increase of GDP, which may eventually improve energy efficiency. Second, the exploitation of natural resources in several BRI nations, particularly in the Middle East, also demands very significant energy consumption. China has invested in and assisted these BRI countries in increasing their fossil energy extraction capacity and technology, as well as lowering energy usage throughout the extraction, resulting in increased energy efficiency. Third, China has built many infrastructures, especially transportation facilities, in cooperation with BRI countries. The infrastructures which China has helped to build, such as high-speed railways, expressways, bridges, and pipelines, will shorten transportation distances and improve the energy efficiency of transportation. Fourth, the financing facilitated by the BRI from some Chinese investors such as the Silk Road Foundation and Asian infrastructure investment banks can boost BRI countries' energy efficiency in several ways: First, it is to help BRI countries build hospitals, schools, and other public service facilities so that improving the level of human capital, which may be of great help to the economic growth and also increase output per unit of energy used. Second, it is to provide funds for the construction of overseas economic and trade cooperation zones or industrial parks to improve the production efficiency and upgrade the industrial level of BRI countries. Third, some service businesses with low energy use and high production are included in China's outward investment, such as the financial industry and information industry, as well as tourism. They use less energy and produce higher output than other industries, thus improving the BRI countries' energy efficiency.

In terms of the influence of trade with China on BRI countries' energy efficiency, the essence of related studies is to analyze whether foreign trade can improve the expected output of energy elements. For example, Boyd and Pang [10] emphasize that increasing energy efficiency is contingent on increasing total factor productivity, while international trade can promote the technological progress and productivity improvement of a country. A few studies have also documented that trade with China has a favorable influence on other countries' energy efficiency [11,12]. On the one hand, exports of high-value-added science and technology products, such as telecommunications, laptops, and high-speed trains, have replaced China's low-end industrial products in recent years, resulting in 
industrial structure upgrades and technology spillovers in BRI countries, especially those in Africa. In addition, China's exports of domestic overcapacity such as energy-intensive products replaced some BRI countries' energy-intensive industries, thus reducing energy consumption and increase energy efficiency in these countries. On the other hand, China's huge import demand stimulated economic activity and income growth, thus increasing output per unit of energy used.

Third, as for the international exchange between China and other BRI countries, many fields including education, science, technology, and culture have risen quickly after the proposal of the BRI, which can help BRI countries improve their human capital and technology and has a favorable influence on energy efficiency. Varied BRI nations have vastly different cultural backgrounds. There are 1023 sister city pairings between China and 61 BRI nations, which represents about half of the total in China [13]. In addition, China has inked agreements with 24 BRI nations on the mutual certification of tertiary education qualifications [13]. China has established the "Silk Road" government scholarship to assist over 10,000 students from those nations [12]. In addition, China has inked intergovernmental agreements on scientific and technical cooperation with 49 BRI nations [14].

The above impact mechanism which we analyzed can be shown in the following Figure 1, which also indicates the research design and methodologies.

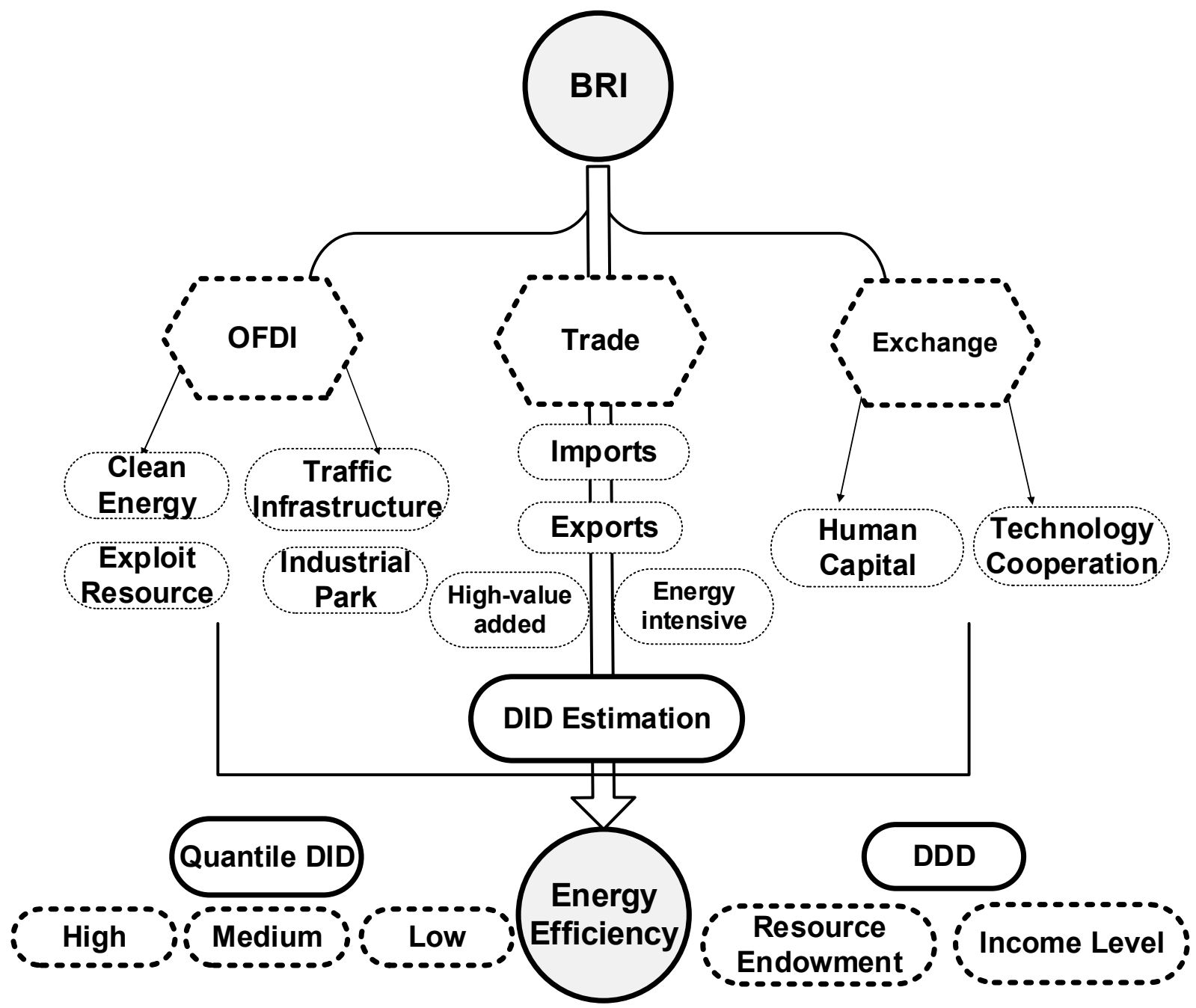

Figure 1. Mechanism and research design. 
This paper mainly uses the counterfactual analysis DID method to estimate the policy effect of participating in the BRI on the energy efficiency of countries along the Belt and Road. Although the DID method can solve the endogeneity problem to a certain extent and the results after a series of tests are credible, the effect of this policy is rather general. To this end, this paper uses the quantile DID method to further discuss the policy impact of BRI at different energy efficiency levels. At the same time, the DDD method is used to discuss the differences in the policy effects of BRI on energy efficiency in different types of BRI countries.

\subsection{Literature Review}

A wide range of energy efficiency-related studies has examined the impact of BRIrelated variables, such as trade [15-19] and FDI [20-25]. Studies have examined the link between the BRI and energy efficiency, with the results falling into three groups.

(1) Positive impacts

According to Han et al. [4], the BRI can enhance energy efficiency convergence among BRI nations via regional cooperation and energy trade with China. Based on the panel data of 48 BRI countries for the period of 1990-2015, Sun et al. [26] also reached a similar conclusion. They also found that high-income BRI countries perform better than the lower-income BRI countries. Based on the panel data of 59 BRI countries for the period of 1996-2015, Qi et al. [27] found that the bilateral trade between China and other BRI countries can promote the energy intensity convergence rate by about $13 \%$ when exceeding the trade threshold value. Especially, BRI countries with larger bilateral trade scales or more technology-intensive imports from China will have higher convergence rates than the others. Similarly, Huang et al. [28] found that the energy intensity convergence among BRI countries will become faster when the globalization level is above the threshold, indicating that deep cross-national cooperation in economic, social, and political areas is needed under the BRI. According to Qi et al. [5], the greater the total factor energy efficiency (TFEE) is in high-income nations where the development and convergence have been more rapid. Festus et al. [29] found that regulating coal rents in the form of carbon harm prices has a substantial yet beneficial effect on $\mathrm{CO}_{2}$ emissions. In an era of global environmental awareness, the need to change the energy balance to renewable sources is critical. According to Gu and Zhou [6], after collecting basic information on clean energy infrastructure projects in BRI countries, China has 36 such projects, with a total capacity of $15.75 \mathrm{Gw}$. A significant push will be provided by China's successful investment and execution of green projects in BRI nations. Liu et al. [30] also observed that the initiative can improve the environmental sustainability of Chinese OFDI in the linked sectors and particularly in developing nations. By studying the carbon intensity in 29 BRI countries (excluding China), Li et al. [31] found that BRI countries tend to achieve a stable carbon intensity in order to achieve environmentally friendly energy and low-carbon development. This suggests that the BRI can be used to reduce global emissions of carbon dioxide and develop green energy globally. Energy efficiency will also be favorably impacted by the energy efficiency of the surrounding regions, suggesting that increasing energy efficiency is also a problem for global governance that requires the involvement of all nations. In addition, by calculating the relationship between renewable energy consumption and carbon emissions among 33 BRI countries from 1986 to 2018, Anwar et al. [32] found that renewable energy consumption tends to reduce the carbon emissions off BRI countries, and investment in renewable energy projects is very important under the BRI. Based on the panel data of 46 BRI countries from 2003 to 2016, Wu et al. [33] found that China's OFDI has an increasing effect on the green total factor productivity of BRI countries, especially those countries with higher institutional quality. Based on the DID method, Wu et al. [34] found that the BRI tends to reduce $\mathrm{CO}_{2}$ intensity in the energy-intensive industries of BRI counties, such as the manufacturing, transportation, electricity, and heating sectors. Based on the panel Granger causality test from 1999 to 2017, He et al. found that renewable energy consumption, carbon intensity, and economic growth have a systematic link in BRI 
countries, indicating that the BRI can help to realize sustainable development through promoting renewable energy development in these countries. Based on the panel data of 24 BRI projects, Abbas et al. [35] found that renewable energy can help BRI countries improve the environment, thus the financial assistance from China in renewable energy sources and technologies is quite positive for realizing sustainable development in these countries. From the panel data of 25 BRI countries from 2005 to 2019, Wang et al. [36] found that the growth in renewable energy scale has a key reducing effect on $\mathrm{CO}_{2}$ emissions in most BRI countries.

\section{(2) Negative impacts}

According to Rauf et al. [2], the Environmental Kuznets Curve (EKC) theory for the BRI countries is used to argue that mega projects are a cause of ecological harm since the BRI requires enormous energy sources to complete the contained projects. A pollution haven hypothesis $(\mathrm{PHH})$ verified model is proposed by Cai et al. [37] to perform a complete examination of the $\mathrm{PHH}$ in a Belt and Road case study. Results reveal that China is a pollution refuge for 22 advanced nations and that it is a pollution haven for 19 underdeveloped countries. Tracy et al. [1] believed that China's green shift might be realized in part through the export of polluting businesses and the deterioration of natural resources in nations that are at the bottom of the global production chain, and hence more vulnerable. According to Ascenso et al. [3], the BRI will have a significant impact on global commerce in the future; however, it may also lead to a lasting deterioration of the ecosystem. Based on the panel data of 33 BRI countries for the period of 2000-2016, Liu et al. [38] suggested that the overall energy efficiency of these countries was continually falling, and the average energy efficiency of the BRI countries has declined since 2013. By applying the data envelopment analysis (DEA) method, Atta Mills et al. [39] found that the overall energy efficiency of 58 BRI countries is relatively lower than other countries, and only 7 West Asian and North African countries are energy efficient. For the panel data of 90 BRI countries for the period of 1990-2017, Ahmad et al. [40] found that there exists a bidirectional causality among finance development, trade openness, and energy consumption with carbon emissions. From a panel data of 47 BRI countries over a period of 1980 to 2016, Rauf et al. [41] found that energy consumption, gross fixed capital, economic growth, financial development, and urbanization may lead to environmental degradation in BRI countries. Based on the panel data of 69 BRI countries from 2000 to 2014, Khan et al. [42] found that technological innovations, economic growth, and foreign direct investment have a negative impact on renewable energy. Similarly, Akbar et al. [43] found that energy efficiency can reduce $\mathrm{CO}_{2}$ emission; however, FDI and GDP will lead to an increase in $\mathrm{CO}_{2}$ emission. In addition, Akbar et al. [44] also analyzed the transport energy efficiency by taking two years as a pre- and post-BRI case, showing that, after the BRI, there is an increase in economic activity but a decline in transport energy efficiency.

\section{(3) Different impacts}

Yang and Wei [45] reviewed the total factor energy efficiency (TFEE) and its affecting variables for 17 major areas of the Belt and Road from 2005 to 2015 and conclude that the TFEE's primary negative drivers are technical changes, coal use, research and development, and environmental degradation. The positive drivers of the TFEE, on the opposite, are pure efficiency changes, changes in the scale of efficiency, economic structure, opening up, and government finances. Chen et al. [46] proposed a DEA technique for assessing BRI nations' low carbon economic process and energy efficiency. According to the study, low-carbon economic growth, high energy efficiency, and high income levels are unrelated. For a group of 59 Belt and Road Initiative (BRI), Shah et al. [47] found that the increase in capital formation, foreign direct investment and open trade improves the quality of the environment, while an increase in income and the consumption of electricity deteriorates the quality of the environment. Based on the panel data of 97 BRI countries from 2002 to 2017, Wu et al. [48] found that import intensity tends to reduce carbon emissions, but export intensity tends to increase carbon emissions of BRI countries, and the impact in the 
resource-rich BRI countries is much bigger than that in the resource-poor BRI countries. Based on the Shapley value decomposition method, Wu et al. [49] also found that the impact of import intensity on the carbon emissions divergence among BRI countries changed after 2009 , but the export intensity has been invariant. For the panel data of 65 BRI countries from 1981 to 2016, Rauf et al. [50] found that energy consumption, high-tech industry, and economic growth deteriorate environmental quality, but financial development and renewable energy consumption have a positive effect on the environment.

To summarize, research on the BRI's influence on energy efficiency are conflicting and inconclusive. Because the BRI nations differ in terms of development, energy efficiency, and resource endowment, the impact of the BRI on their energy efficiency may vary. However, no research has been done to look at the possible differences in impact owing to the BRI countries' efficiency, income, and resource endowment simultaneously. This study differs from prior studies in the following three ways: first, we analyze the impacts of BRI on BRI nations' energy efficiency by using panel data of 178 countries from 2002 to 2018, and the result passes the robustness checks. Second, the quantile DID technique was used to examine the BRI's heterogeneous effectiveness at various degrees of energy efficiency. Third, we use the DDD approach to estimate the effects of the BRI on energy efficiency for distinct BRI country groups with varied resource endowments and income levels, resulting in diverse practical consequences for separate country groups under the BRI.

\section{Variable, Model, and Data Source}

\subsection{Methods}

One of the most straightforward ways to measure a policy's impact is to compare differences in outcomes across the treated groups before and after implementation. However, because economic conditions vary both before and after the implementation of a policy, the difference between the two of them does not always stem from the policy effect.

In order to resolve this issue, we will employ the difference in difference (DID) approach to examine the BRI's impact on the energy efficiency of related nations in order to determine the root cause. By using a control group that was not in the policy area, first, we must compute the difference between the control group prior to and after the policy's adoption as a time impact for the treatment group. This is known as the treatment group's time effect. Second, the difference in the control group before and after is subtracted from the difference in the treatment group in order to produce a more accurate policy effect estimate [51]. As a kind of natural experiment, the DID approach may successfully manage the unachievable heterogeneity and impact of inalienable elements over time and avoid the shared causalities between variables, resolving the endogenous issue of the policy variable to some degree. However, the results of the DID method are just the combined impact of the policy variable on the dependent variable, and it cannot reflect the specific effects in different situations.

Therefore, for the country data in this paper, the differences in three dimensions of the region, time, and different types of countries can be taken into account by using the DDD model. The traditional DID model can only measure the difference between two dimensions (region and time), while the DDD model can measure the difference between three dimensions on the original basis. In the empirical part, BRI countries are divided into different groups in two ways, which are resource endowments and income levels.

For natural resource endowments, the classification is from the gross rent of natural resources (as a percentage of GDP), which is an index of the world bank database. Gross rents for resources are the total rents for coal (hard and soft), oil, minerals, forests, and gas. If the average index of a nation between 2002 and 2018 exceeds the mean value of the BRI countries, the index is classed as the country rich in natural resources; otherwise, the index is categorized as the country low for natural resources. For income levels, because of differences in average annual income between 2002 and 2018, nations categorized as high-income above the average or low-income below the average will be categorized as high-income or low-income groups in that particular year. 


\subsection{Variables}

In this study, the execution of the policy is the key variable and is measured by the signature of the MOU. The Belt and Road Initiative links the eastern Pacific Ocean with the western Baltic Sea, spanning Europe, Asia, and Africa and including 65 countries [52]. Therefore, the countries in the Silk Road area that have signed MOU with China are defined as BRI countries, which constitute the treatment group, and other countries which are not in the area and did not participate in the BRI constitute the control group for the DID model. As the mechanism analysis in Section 3.1, we assume that it has a positive impact on energy efficiency in BRI countries.

The dependent variable energy efficiency is calculated as the proportion of GDP to fossil fuels use, where GDP is measured in US dollars at the 2011 constant price and the fossil use is measured in a kilogram of oil equivalent. In reality, energy efficiencies in BRI countries are generally quite low due to low technology levels and backward industries. BRI countries are mainly dependent on agricultural and resource industries and manufacturing industries, and their economic development is heavily dependent on energy-intensive industries. Meanwhile, their energy conservation and emission reduction technologies are generally backward, leading to the rapid growth in energy consumption and carbon emissions. In view of the difficulty of rapid industrial upgrading and technological progress in a short time, the solutions mainly focus on gradually increasing the output per unit of energy consumption, namely, energy efficiency, and developing clean energy to replace the fossil energy. Therefore, energy efficiency involves both the amount of energy use of a country and the amount of output it produces, and improvements in energy efficiency can reduce energy consumption while maintaining a certain rate of economic growth in developing BRI countries.

In addition, variables anticipated to impact energy efficiency in BRI nations were controlled for accurately empirical investigations.

To begin with, urbanization will undoubtedly increase energy consumption and economic growth, and then has an effect on energy efficiency [53]. For most developing countries with high economic growth, the impact of urbanization on energy efficiency is generally negative [54,55]. It is written as UR [16] and is defined as the percentage of city dwellers in the total population in this paper where the unit is \%. According to the Kuznets curve for the environment, while urbanization is low, it could waste too much energy and reduce energy efficiency; once it reaches a turning point, it could enhance energy efficiency [56]. Because the urbanization level is quite different among BRI countries, we do not make predictions about its impact.

Second, the upgrade of industrial structures, especially the upgrading of tertiary industries, may have an influence on boosting energy efficiency. It is generally acknowledged that reducing the ratio of industry added value to the GDP and stimulating technological progress can continuously reduce energy intensity, thus increasing energy efficiency [57]. Energy efficiency variation presents an obvious feature of industrial economy transformation [58]. The industrial structure in this research is controlled by utilizing the ratio of value-added to GDP from the service sector and is referred to as SER [59], where the unit is \%. The larger the GDP share of the tertiary industry, the better the energy efficiency is predicted to be.

Third, one of the most important elements impacting energy efficiency is economic growth. Generally, economic growth can promote energy efficiency in higher-income countries while restraining energy efficiency in lower-income countries. In a word, the positive relationship between economic growth and energy efficiency increases as the countries reach from low-income level to high [60]. In particular, individual developing countries with faster economic growth have improved energy efficiency rapidly, such as India, which has changed its fossil-fuel-based, energy-led economic growth pattern to a growth model driven by energy efficiency [61]. To manage the degree of economic progress, we utilize the constant price of GDP per capita in 2010 US dollars, denoted as PGDP [15]. Based on the environmental Kuznets curve, when economic development is modest, 
economic progress may become too reliant on energy use, and it may decrease energy efficiency; after reaching the turning point, the energy efficiency may increase because of the transformation of the growth model, stricter laws, and increased environmental awareness at a certain level of economic development. Similar to urbanization, we do not make predictions about its impact.

Fourth, a substantial impact on energy efficiency might be had by the combination of energy usage, particularly renewable energy usage. The development of renewable energy is closely related to energy conservation, emission reduction and energy efficiency [62]. Despite the moderately improved efficiency of coal and oil energy, its relatively low level contributes most to the overall energy inefficiency because it is the main fuel used in most developing countries [63]. Therefore, the improvements in the use of clean energy make it of importance to increasing energy efficiency. The energy consumption structure is defined as the renewable energy consumption share over the final energy consumption and is referred to as ENC $[64,65]$, where the unit is \%. The greater the share of renewables used in the final energy consumption, the more energy efficiency is anticipated.

Fifth, open trade may have a major effect on energy efficiency. Most of the previous relevant studies believe that a country's trade openness and reduction of barriers can improve energy efficiency through some channels such as promoting technology spillover and industrial upgrading, especially for developing countries [66-68]. The proportion of imports and the exports to GDP is regarded as the index of open trade and is referred to as OPEN [18,69], where the unit is \%. Imports may replace excessive energy consumption and poor energy efficiency with some manufacturing, while exports may lead to increased revenue and output. Therefore, the greater the openness to commerce, the better the energy efficiency.

Sixth, we manage the stock of FDI. Some studies considered that foreign direct investment enhanced the energy efficiency significantly and there is no increase in pollution, which demonstrated the "pollution halo" effect [70-73]. Others believed that foreign direct investment increased pollution and was not beneficial to energy efficiency, which demonstrated that the "pollution haven" effect was greater than the "pollution halo" effect [74-77]. In this research, FDI is described as the FDI share over GDP and is referred to as FDI/GDP [78], where the unit is \%. If the FDI industry concentrates on the heavy industry or other industries with low energy efficiency, FDI may decrease energy efficiency. If concentrated on the service sector or other industries with high energy efficiency, FDI may increase energy efficiency. In short, the energy efficiency effect of FDI mainly relies on the kind of sector in which it invests. Consequently, we do not prejudge FDI's total effect on energy efficiency.

Ultimately, human capital is a key driver of clean energy development and energy efficiency improvement since it leads to technological advancement and environmental consciousness. One essential positive externality of human capital development is that it promotes a greener future through energy conservation [79]. The proportion of the population in higher education in the general population between the ages of 18 and 22 is defined as human capital and is defined as EDU [80], where the unit is \%. It is expected that the higher level the of human capital, the higher the energy efficiency.

A few variables may have an impact on energy efficiency but are not included because the data is not available, such as energy-saving policies, energy-saving technology level, and government control over energy prices. Omission of important variables may lead to endogeneity problems and bias the estimation results. However, our subsequent robustness tests show that there is no problem of missing important variables, and the DID method, as a natural experimental method, can reduce the impact of missing variables to a certain extent. 


\subsection{Econometric Models}

This study adopts the DID approach and proposes the involvement of BRI as a quasi-natural experiment to explore its impact on energy efficiency in BRI countries. As mentioned earlier, the treatment group is chosen for the BRI countries while the control group is chosen for non-BRI countries, and the corresponding DID models are formed:

$$
E E_{i t}=\beta B R I_{i} \cdot \text { Post }_{i t}+\gamma X_{i t}+u_{i}+v_{t}+\varepsilon_{i t}
$$

Equation (1) is a DID regression model which takes into consideration both timing and country-fixed factors in addition to random variables. In the equation, $i$ represents the nation ranging from 1 to 178 , and $t$ represents the year ranging from 2002 to 2018 . $E E_{i t}$ is the energy efficiency that is being used as the dependent variable in this research. Post $_{i t}$ is a dummy variable that represents the influence of BRI policy on the processing time. For Post ${ }_{i t}$, country $i$ and China signed a BRI MOU and the year of signing and the years afterward are set to 1 . It is set to 0 for the years immediately before that. When processing the Belt and Road Initiative group, $i$ is used to indicate whether a nation is located within the Belt and Road Initiative region. If there is a nation along the routes, this variable should be set to 1 , otherwise it should be set to 0 . The interaction term between $B R I_{i}$ and Post $_{i t}$, which is the fundamental variable addressed by the DID technique, is denoted by the symbol $B R I_{i} \cdot$ Post $_{i t}$. Urbanization, industry structure, per capita income, energy use structure, open trade, foreign direct investment, and human capital are control factors and constitute $X_{i t}$ for economic features that might influence energy efficiency. In this equation, $v_{t}$ denotes the year fixed effect, $u_{i}$ is the country fixed effect, and $\varepsilon_{i t}$ denotes the random disturbance factor. We are particularly interested in the coefficient $\beta$ of the variable $B R I_{i}$. Post $t_{i t}$, whose economic significance may be explained by the influence of BRI on energy efficiency.

Based on the DDD method, Equation (1) can be expanded to Equations (2) and (3) as the model (2) and model (3). These are calculated as follows:

$$
\begin{aligned}
E E_{c t i}= & \beta B R I_{c} \cdot \text { POST }_{t} \cdot \text { RESR }_{i}+\eta_{1} \text { BRI }_{c} \cdot \text { POST }_{t}+\eta_{2} \text { BRI I }_{c} \cdot \text { RESR }_{i} \\
& +\eta_{3} \text { RESR }_{i} \cdot \text { POST }_{t}+\gamma X_{c t}+u_{c}+v_{t}+\lambda_{i}+\varepsilon_{c t i} \\
E_{c t j}= & \beta B R I_{c} \cdot \text { POST }_{t} \cdot \text { LOWI }_{j}+\eta_{1} \text { BRI }_{c} \cdot \text { POST }_{t}+\eta_{2} \text { BRI I }_{c} \cdot \text { LOWI }_{j} \\
& +\eta_{3} \text { LOWI }_{j} \cdot \text { POST }_{t}+\gamma X_{c t}+u_{c}+v_{t}+\lambda_{j}+\varepsilon_{c t j}
\end{aligned}
$$

In Equation (2), time, country, and resource fixed effects are taken into consideration while estimating the DDD results. Equation (2) adds the variable $R E S R_{i}$ to the equation, which indicates whether a nation is in the group of resource-rich countries or one of the resource-poor countries, in addition to the variables described in Equation (1). For RESR ${ }_{i}$, if one country belongs to the resource-rich country, it is set as 1 , otherwise, it is set as 0 . $\lambda_{i}$ is the resource fixed effect. To estimate the time, country, and income fixed effects in the DDD estimating model (3), the following must be used: $L O W I_{j}$ in the formula is a dummy variable that indicates whether a nation is a low-income country or a high-income country. To determine if a nation falls into the low-income category, the variable $L O W I_{j}$ is assigned to 1 , otherwise, to $0 . \lambda_{j}$ represents the income fixed effect. The influence of BRI on energy efficiency may be used to explain the coefficient $\beta$ in Equations (2) and (3). In addition, to control time trends in the treatment groups, we add cross-terms $B R I_{c} \cdot P O S T_{t}, B R I_{c} \cdot R E S R_{i}$, $R E S R_{i} \cdot P O S T_{t}, B R I_{c} \cdot L O W I_{j}$, and LOWI $\cdot P O S T_{t}$, respectively, in Equations (2) and (3).

\subsection{Data Sources}

The panel data, comprising 178 nations and regions, covering 63 Silk and Road countries from 2002 to 2018, omitting Palestine and Bhutan due to a lack of data on energy efficiency and 115 others, are used in this paper.

The data of the years for signing MOU between BRI countries and China are from the Chinese government's Belt and Road Portal (https:/ / www.yidaiyilu.gov.cn/gbjg/gbgk/ 
77073.htm, accessed on 8 August 2021) [81], which is for the variable MOU. The data on energy efficiency comes from the International Energy Agency (IEA) Statistics (https: / / www.iea.org/ data-and-statistics, accessed on 8 August 2021) [7], which is for the variable $E E$. The data of share of FDI stock over GDP come from the World Investment Report of United Nations Conference on Trade and Development (UNCTAD) (https: / / unctadstat. unctad.org/EN/, accessed on 8 August 2021) [82], which is for the variable FDI/GDP. The World Bank provides all of the additional variables' data (https: / / databank.worldbank.org/ source/world-development-indicators, accessed on 8 August 2021), including urbanization level (UR), industrial structure (SER), GDP per capita (PGDP), renewable energy share (ENC), trade openness (OPEN), the proportion of the population with higher education (EDU), as well as the gross rent of natural resources for the classification of BRI countries in different resource endowments [83].

\section{Empirical Results and Analyses}

\subsection{The Impact of BRI on Energy Efficiency}

We add the national fixed effect, the year fixed effect, and the BRI time trend impact over time in small increments, as indicated in Equation (1) of Section 3.2. At the national level, the standard errors are clustered. The energy efficiency may be changing more naturally in BRI nations than in other countries and areas, independent of the policy changes brought forth by the BRI. For example, the majority of BRI countries are in the process of economic development. The gradual improvement of the technology level, industrial structure, and other factors of these countries will lead to the increase of their energy efficiency.

Ignoring the underlying trend change of dependent variables in the treatment group will produce the bias of missing variables and make the estimated results biased. Referring to Li et al. [84], as indicated in column (2) of Table 1, a time-varying variable $t$ representing the time trend is defined, and a cross term between the BRI and $t$ is included in the equation. It is through this interaction item that the expected trends in energy efficiency in the treatment group may be controlled. The coefficient of the variable BRI $\times$ POST in column (2) is somewhat bigger and more statistically significant than the coefficient in column (1), as shown in Table 1, showing that the results after adding the cross term are more dependable than the results of column (1).

If the treatment group's dependent variables are not taken into account for their underlying trend changes, the estimated findings will be skewed. A continuous-time trend variable $t$ and a cross term between the $t$ and the BRI are suggested by Li et al. [84]. This is represented in column (2) of Table 1 . The energy efficiency is determined by this interaction item. According to Table 1, the coefficient of the cross term BRI.POST in column (2) is marginally bigger and more significant, implying that it is more resilient despite the little difference between them.

Based on Model (1), energy efficiency has grown considerably in BRI countries as a result of BRI policies. The coefficients of the variable BRI-Post were significantly positive at the $10 \%$ and $5 \%$ levels, as shown in columns (1) and (2), respectively. It shows that the policy of BRI has a significantly increasing effect on the energy efficiency of BRI countries, which is consistent with our assumption in Section 3.1 and previously related literature (e.g., 26-36). Actually, according to the energy efficiency data of BRI countries available in this paper, the average energy efficiency of the BRI countries has risen from 8.62 in the year 2012 to 9.04 in the year 2018. 
Table 1. Energy efficiency regression findings.

\begin{tabular}{|c|c|c|}
\hline \multirow[t]{2}{*}{ Dependent Variable } & \multicolumn{2}{|c|}{ Energy Efficiency } \\
\hline & (1) & (2) \\
\hline BRI·Post & $\begin{array}{l}2.425 * \\
(0.062)\end{array}$ & $\begin{array}{c}3.043 * * \\
(0.014)\end{array}$ \\
\hline EDU & $\begin{array}{c}0.032 * * * \\
(0.000)\end{array}$ & $\begin{array}{c}0.035 * * * \\
(0.000)\end{array}$ \\
\hline FDI/GDP & $\begin{array}{c}0.001 \\
(0.742)\end{array}$ & $\begin{array}{c}0.001 \\
(0.505)\end{array}$ \\
\hline ENS & $\begin{array}{c}0.033 * * * \\
(0.000)\end{array}$ & $\begin{array}{c}0.034^{* * *} \\
(0.000)\end{array}$ \\
\hline PGDP & $\begin{array}{c}0.001 * * * \\
(0.002)\end{array}$ & $\begin{array}{c}0.001 * * * \\
(0.004)\end{array}$ \\
\hline OPEN & $\begin{array}{c}0.008^{* * *} \\
(0.004)\end{array}$ & $\begin{array}{c}0.007^{* * *} \\
(0.009)\end{array}$ \\
\hline UR & $\begin{array}{c}-0.016 \text { * } \\
(0.094)\end{array}$ & $\begin{array}{c}-0.014 \text { * } \\
(0.080)\end{array}$ \\
\hline SER & $\begin{array}{c}0.114^{* * * *} \\
(0.000)\end{array}$ & $\begin{array}{c}0.119^{* * *} \\
(0.000)\end{array}$ \\
\hline R square & 0.251 & 0.268 \\
\hline Year-fixed effect & $\mathrm{Y}$ & $\mathrm{Y}$ \\
\hline Nation fixed effect & $\mathrm{Y}$ & $\mathrm{Y}$ \\
\hline $\mathrm{BRI} \times$ Time trend & & Y \\
\hline Observations & 1791 & 1791 \\
\hline
\end{tabular}

Source: data analysis. Notes: $p$-values are in brackets ${ }^{*} p<0.1,{ }^{* *} p<0.05,{ }^{* * *} p<0.01$.

In addition, most of the control variables are positively and statistically significant at the 1 percent level with coefficients for all four variables, including human capital, energy consumption structure, per capita GDP, and industrial structure, suggesting that the boost in human capital, the transformation to renewable energy use, economic growth, and industrial development have increasing effects on energy efficiency. On the one hand, the level of urbanization is negative and significant at $10 \%$ statistically, which means that the current phase of urbanization will decrease the energy efficiency. It indicates that in most BRI nations, the urban development is at a low level and depends too much on the use of fossil energy. On the other hand, the trade openness coefficient is positive and significant at the $1 \%$ level statistically, which corresponds to our earlier theories and predictions. The coefficient of the variable of FDI stock is nevertheless positive and not statistically significant. The potential explanation is that the stock and flow of foreign capital is still relatively modest, not having a direct effect on the BRI nations' energy efficiency.

As shown in Table 2, energy efficiency is split into 18 quantiles, from high to low, to examine the energy efficiency effects of BRI at various degrees of energy efficiency based on the quantile DID technique in BRI countries. No additional variable findings are displayed in the table due to limited space. It is found that at the $0.05,0.1,0.15$, and 0.3 quantile levels of energy efficiency, the effects of BRI are not significant. However, in other medium or high quantile levels, the BRI policy effects are all significant. This may be due to the lack of innovation and the capacity of technology in the lowest energy efficiency and maybe less-developed BRI countries [5]. The cooperation with China under the BRI is more about poverty alleviation than increasing energy efficiency.

\subsection{Analysis of Validity and Robustness}

For one reason, the selection error of samples may result in incorrect DID findings. In addition, the policy impacts may not be the gap before and after policy adoption. The results of DID are not trustworthy in this situation. Multiple tests must thus be carried out to ensure that the results fulfill the validity and robustness of the DID technical data. 
Table 2. The results of regression using the quantile method.

\begin{tabular}{ccccccccccc}
\hline Quantile & $\mathbf{0 . 0 5}$ & $\mathbf{0 . 1 0}$ & $\mathbf{0 . 1 5}$ & $\mathbf{0 . 2 0}$ & $\mathbf{0 . 2 5}$ & $\mathbf{0 . 3 0}$ & $\mathbf{0 . 3 5}$ & $\mathbf{0 . 4 0}$ & $\mathbf{0 . 4 5}$ \\
\hline BRI·Post & 2.231 & 0.951 & 1.821 & $2.789^{* *}$ & $3.669^{* * *}$ & 0.480 & $1.369^{*}$ & $2.321^{*}$ & $1.722^{* *}$ \\
control & $(0.531)$ & $(0.215)$ & $(0.336)$ & $(0.020)$ & $(0.000)$ & $(0.709)$ & $(0.052)$ & $(0.074)$ & $(0.046)$ \\
variables & $\mathrm{Y}$ & $\mathrm{Y}$ & $\mathrm{Y}$ & $\mathrm{Y}$ & $\mathrm{Y}$ & $\mathrm{Y}$ & $\mathrm{Y}$ & $\mathrm{Y}$ & $\mathrm{Y}$ \\
observations & 1791 & 1791 & 1791 & 1791 & 1791 & 1791 & 1791 & 1791 & 1791 \\
R square & 0.18 & 0.12 & 0.10 & 0.11 & 0.12 & 0.12 & 0.12 & 0.13 & 0.13 \\
\hline Quantile & $\mathbf{0 . 5}$ & $\mathbf{0 . 5 5}$ & $\mathbf{0 . 6}$ & $\mathbf{0 . 6 5}$ & $\mathbf{0 . 7}$ & $\mathbf{0 . 7 5}$ & $\mathbf{0 . 8}$ & $\mathbf{0 . 8 5}$ & $\mathbf{0 . 9}$ \\
\hline BRI·Post & $2.259^{* *}$ & $2.480^{* *}$ & $2.874^{* * *}$ & $3.331^{* * *}$ & $3.993^{* * *}$ & $4.034^{* * *}$ & $3.113^{* *}$ & $4.651^{* *}$ & $2.214^{*}$ \\
control & $(0.027)$ & $(0.023)$ & $(0.003)$ & $(0.005)$ & $(0.002)$ & $(0.004)$ & $(0.020)$ & $(0.013)$ & $(0.077)$ \\
variables & $\mathrm{Y}$ & $\mathrm{Y}$ & $\mathrm{Y}$ & $\mathrm{Y}$ & $\mathrm{Y}$ & $\mathrm{Y}$ & $\mathrm{Y}$ & $\mathrm{Y}$ & $\mathrm{Y}$ \\
observations & 1791 & 1791 & 1791 & 1791 & 1791 & 1791 & 1791 & 1791 & 1791 \\
R square & 0.14 & 0.15 & 0.15 & 0.14 & 0.14 & 0.15 & 0.14 & 0.16 & 0.18 \\
\hline
\end{tabular}

Source: data analysis. Notes: $p$-values are in brackets ${ }^{*} p<0.1,{ }^{* *} p<0.05,{ }^{* * *} p<0.01$.

As a first step, we compare the mean energy efficiency values of the control and treatment groups after the policy change. There is no statistically significant difference between the two periods, as shown by the $p$-value of 0 . Energy efficiency is different for the two following BRI deployments, according to the data.

Secondly, we do a parallel trend analysis before the policy occurs. To be valid, the mean values of treatment and control groups need not be identical, but the trends between groups should be similar before the policy event. So that we could test this hypothesis, we built up an interaction item $B R I \times$ dumyear that reflects the possible differences in energy efficiency trends between the two groups. Because of this, we are primarily concerned with comparing the two groups in the years before and after the BRI was enacted, which could not only reflect the parallel trend before the policy but also observe the effect after the policy.

As shown in Figure 2, the cross term BRI $\times$ dumyear between BRI and year dummy variable is close to 0 in the policy year and the years before, and then significantly positive, indicating that the evolving patterns of the treatment group and control group in the policy year and years preceding the implementation of the BRI are the same, with no significant difference, in line with the parallel trend hypothesis. In the year when MOU is signed, the effect of the BRI is not obvious. However, in the years after the policy, it does not contain 0 in the $99 \%$ confidence interval; that is, at the one percent level, the cross-term coefficient is statistically significantly positive, suggesting that the cross-term has a statistically significant positive policy effect and that there is a statistically significant difference between the treatment group and the control group. Because the BRI has a lagging influence on energy efficiency, such as the fact that the impact of the initial investment will not occur until it is done, it is fair to expect the policy effect to be delayed by one year after the investment project is completed.

Third, similar to Topalova [85], at a period previous to 2013, the placebo test establishes BRI policy events. From 2005 to 2012, we estimate the difference to determine if the effect on energy efficiency is still favorable. As shown in the preceding study, the basis of the DID approach is that the energy efficiency trend before the event is not considerably different. The calculated coefficient of the key variable should not be significant if the policy event is established in a time before 2013. If the findings are opposite, then it is implied that potential non-observed variables other than BRI might lead to increases in the energy efficiency of BRI nations. In order to assure the robustness of the model, the policy impact years have been established as 2012, 2011, 2010, 2009, 2008, 2007, 2006, and 2005, as well as the years following those years, where appropriate. Columns (1) to (8) in Table 3 respectively report the corresponding estimated results, which indicate that the estimated coefficients are all insignificant and the DID regression results are robust. 


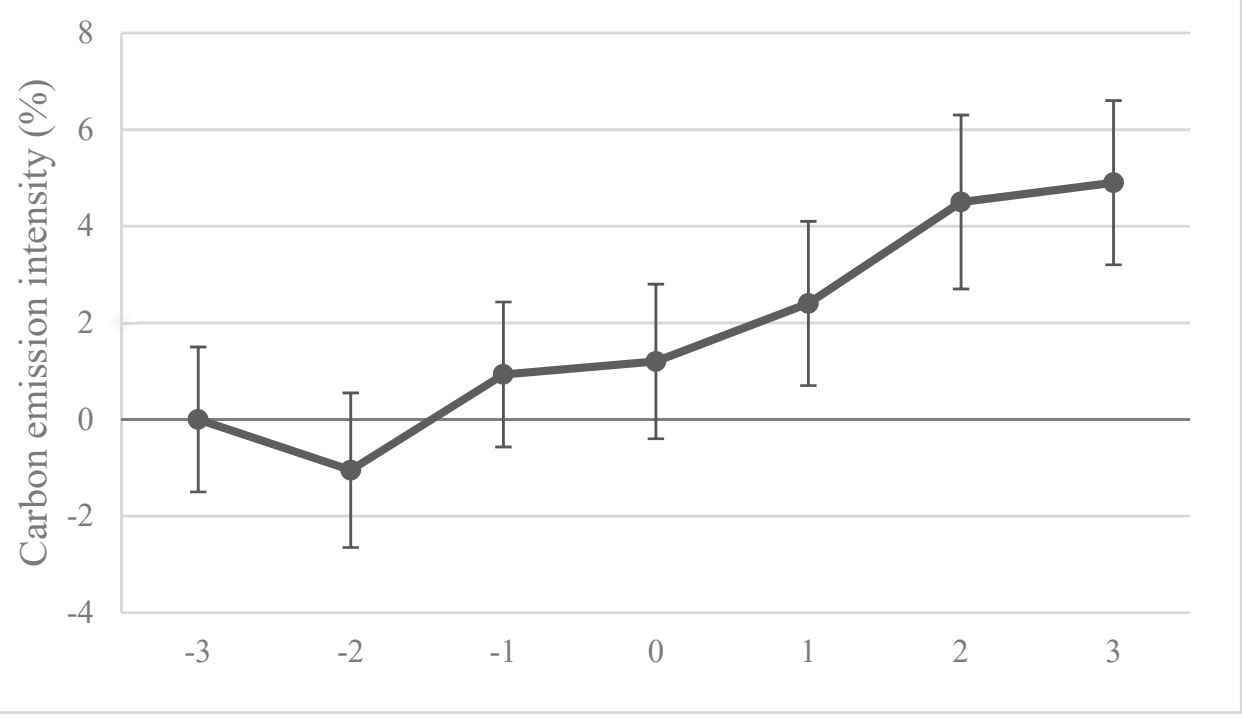

Figure 2. Testing parallel trend.

Table 3. Placebo robustness test.

\begin{tabular}{ccccccccc}
\hline & $\mathbf{( 1 )}$ & $\mathbf{( 2 )}$ & $\mathbf{( 3 )}$ & $\mathbf{( 4 )}$ & $\mathbf{( 5 )}$ & $\mathbf{( 6 )}$ & $\mathbf{( 7 )}$ & $\mathbf{( 8 )}$ \\
\hline Policy year & 2005 & 2006 & 2007 & 2008 & 2009 & 2010 & 2011 & 2012 \\
\hline BRI-Post & 1.563 & 1.083 & 1.725 & 1.467 & 1.362 & 1.757 & 0.964 & 1.386 \\
$(0.362)$ & $(0.521)$ & $(0.728)$ & $(0.662)$ & $(0.693)$ & $(0.522)$ & $(0.416)$ & $(0.457)$ \\
\hline $\begin{array}{c}\text { Control } \\
\text { variables }\end{array}$ & $\mathrm{Y}$ & $\mathrm{Y}$ & $\mathrm{Y}$ & $\mathrm{Y}$ & $\mathrm{Y}$ & $\mathrm{Y}$ & $\mathrm{Y}$ & $\mathrm{Y}$ \\
\hline Observations & 1791 & 1791 & 1791 & 1791 & 1791 & 1791 & 1791 & 1791 \\
\hline R square & 0.249 & 0.252 & 0.255 & 0.246 & 0.248 & 0.251 & 0.249 & 0.254 \\
\hline
\end{tabular}

Source: data analysis. Notes: $p$-values are in brackets.

\subsection{BRI's Disparate Effects on Energy Efficiency in Various Types of Nations}

The influence of the BRI on energy efficiency may vary depending on the kind of country. For example, China has helped build vast amounts of clean energy infrastructure, such as hydropower stations and wind farms, to meet the electric power needs in low-income BRI countries, which can not only reduce the use of fossil fuels but also help BRI countries develop their economies. In addition to cooperating on clean energy infrastructure, China has invested and helped resource-rich BRI countries improve their traditional fossil energy extraction capacity and technology. As a result, low-income nations are more likely to benefit from China's BRI than high-income countries, and it also increases the energy efficiency in resource-rich countries more than that in resource-poor countries. In this section, the DDD method is used to further discuss the heterogeneous impacts of BRI on energy efficiency in different types of countries.

Based on model (2), Table 4 shows that the $B R I_{c} \cdot P O S T_{t} \cdot R E S R_{i}$ variable is positive and statistically significant at the 10 percent level, indicating that participation in the BRI tends to increase energy efficiency in resource-rich countries more than that in resourcepoor countries, which is consistent with our analysis in Section 2.1 and previously related literature (e.g., 39 and 48). The main reason may be that, first, China has invested in many projects in resource extraction of resource-rich BRI countries for reducing energy consumption through improving their fossil energy extraction capacity and technology. 
Second, China has imported a large number of resources, especially energies from resourcerich countries, thus stimulating their income growth. Third, in recent years, Chinese exports of value-added items, such as telecommunications, laptops, and high-speed trains, can lead to spillovers in technology and the upgrading of industrial structures in the BRI nations, especially in resource-rich African countries. Fourth, China's exports of domestic overcapacity, especially of energy-intensive products, can replace these BRI countries' related industries, thus reducing energy consumption and increasing energy efficiency.

Table 4. Regression results by the DDD method.

\begin{tabular}{|c|c|c|}
\hline \multirow[t]{2}{*}{ Dependent Variable } & \multicolumn{2}{|c|}{ Energy Efficiency } \\
\hline & Resource Endowment & Income Level \\
\hline$B R I_{c} \cdot P^{\prime} S_{t} \cdot R E S R_{i}$ & $\begin{array}{l}5.231 \text { * } \\
(0.052)\end{array}$ & \\
\hline$B R I_{c} \cdot P^{\prime} T_{t} \cdot L O W I_{j}$ & & $\begin{array}{c}2.888^{* * * *} \\
(0.000)\end{array}$ \\
\hline EDU & $\begin{array}{c}0.037^{* * *} \\
(0.000)\end{array}$ & $\begin{array}{c}0.024^{* * *} \\
(0.000)\end{array}$ \\
\hline FDI/GDP & $\begin{array}{l}0.001 \text { * } \\
(0.095)\end{array}$ & $\begin{array}{l}0.001 \text { * } \\
(0.084)\end{array}$ \\
\hline ENS & $\begin{array}{c}0.036^{* * *} \\
(0.000)\end{array}$ & $\begin{array}{c}0.032 * * * \\
(0.000)\end{array}$ \\
\hline PGDP & $\begin{array}{c}0.001^{* * * *} \\
(0.001)\end{array}$ & $\begin{array}{c}0.001^{* * * *} \\
(0.000)\end{array}$ \\
\hline OPEN & $\begin{array}{l}0.007^{* *} \\
(0.011)\end{array}$ & $\begin{array}{c}0.008^{* * * *} \\
(0.002)\end{array}$ \\
\hline UR & $\begin{array}{c}-0.013 \\
(0.154)\end{array}$ & $\begin{array}{l}-0.012 \\
(0.198)\end{array}$ \\
\hline SER & $\begin{array}{c}0.078^{* * *} \\
(0.000)\end{array}$ & $\begin{array}{c}0.120 * * * \\
(0.000)\end{array}$ \\
\hline R square & 0.272 & 0.286 \\
\hline Other cross-terms & $\mathrm{Y}$ & $\mathrm{Y}$ \\
\hline Year FE & $\mathrm{Y}$ & $\mathrm{Y}$ \\
\hline Nation FE & $\mathrm{Y}$ & $\mathrm{Y}$ \\
\hline Resource FE & $\mathrm{Y}$ & \\
\hline Income FE & & $\mathrm{Y}$ \\
\hline Resource*Year trend & $\mathrm{Y}$ & \\
\hline Income*Year trend & & $\mathrm{Y}$ \\
\hline Nation*Year trend & $\mathrm{Y}$ & $\mathrm{Y}$ \\
\hline Observations & 1791 & 1791 \\
\hline
\end{tabular}

Based on Model (3), the variable $B R I_{c} \cdot P O S T_{t} \cdot L O W I_{j}$ is positive and statistically significant at the level of $1 \%$, which means that in low-income nations, the BRI tends to enhance energy efficiency more than in high-income countries, which is consistent with our analysis in Section 2.1 and previously related literature (e.g., 26 and 30). In addition, there could be a number of reasons for this finding. First, Chinese investment in the clean energy industries, such as hydropower stations and wind farms can reduce the use of fossil fuels. Second, Chinese OFDI in transportation infrastructure with comparative advantage can improve the economy as well as the energy use efficiency in low-income countries. Third, China helped BRI countries build hospitals, schools, and other public service facilities so that improving the level of human capital and economy. Fourth, the construction of China's trade and economic cooperation areas and industrial parks abroad can improve the production efficiency and upgrade the industrial level of local BRI countries. Fifth, some of China's foreign investments in the service industry, for example, the financial and information industries, have low energy consumption and high production that can increase BRI nations' energy efficiency. The knowledge exchanges and collaboration in 
technology and education under the BRI can finally contribute to improving BRI nations' energy efficiency and reduction technologies.

Moreover, in terms of control variables, the FDI share of GDP is positive and statistically significant at 10 percent for energy efficiency in the two DDD models, which shows that the FDI has a higher energy efficiency effect in BRI low-income countries than that in the high-income BRI countries and has more energy efficiency impacts in resource-rich BRI countries than that in the resource-poor countries. A possible explanation is that less-developed countries are short in capital, and foreign capital plays a greater role in their domestic technological progress, industrial upgrading, and energy efficiency improvement; China's investment in the resources sector has raised the technology level of the industry in the resource-rich BRI countries while importing large amounts of resources to boost output level. In addition, the impact of urbanization in the two DDD models is both statistically insignificant. This implies that no major variances exist in the level of influence on the energy efficiency of urbanization between resource-rich and resource-poor nations, as well as high-income and low-income ones. In other words, it shows that cooperation such as trade and investment from China has little correlation with the urbanization level of the BRI countries.

\section{Conclusions, Policy Implications, and Discussions}

Based on the DID approach, this study focuses on the varied implications of the BRI on participating nations' energy efficiency. Subsequently, the potential effects at different energy efficiency levels are investigated by the quantile DID method. Furthermore, through the DDD technique, the heterogeneous impacts in different BRI countries are discussed based on different resource endowments and income levels. We infer the following conclusion on the basis of the outcomes of this investigation.

Firstly, the study found that participation in the BRI, on average, has had a significantly positive effect on the energy efficiency of BRI countries. The tests based on the average test, the parallel trend test, and the placebo test show that the finding is reliable. Second, in medium and high energy efficiency quantities, the beneficial impacts of the BRI are considerable, while in low energy efficiency quantities, they are not significant. Third, the BRI tends to increase more energy efficiencies in resource-rich countries than those in resource-poor countries and tends to increase more energy efficiencies in low-income countries than those in high-income countries.

With the BRI, member nations may improve their energy efficiency and environmental sustainability, which can help them compete more effectively in the global marketplace. Therefore, in the course of investment and trade, China should avoid the transfer of overpolluting production capacity, and focus on the development of clean energy, transportation infrastructure, cooperation in science, technology and education, and high-tech industries.

First, for low-energy efficiency BRI countries, China can stimulate energy investment, trade, and technical cooperation, especially by providing aids and loans to develop clean energy infrastructure, helping them to increase energy efficiency while meeting their own energy needs for development. Second, for high-energy efficiency BRI countries, infrastructure connectivity is a prior cooperation area, and China can invest more in transportation and energy projects so as to facilitate their economic development, meet Chinese energy requirements, and further improve the energy efficiency through technology spillover from China. Third, for resource-rich BRI countries, China needs to further invest and help them improve their fossil energy extraction capacity and technology for increasing their energy efficiencies. Fourth, for resource-poor BRI countries, the export of high value-added products with strong technology spillover and the shares of knowledge will increase the potential and power of their economic growth and also the energy efficiency. Fifth, for low-income BRI countries, China can continue to import labour-intensive products and natural resources to increase their incomes, and at the same time, directly invest in some manufacturing industries with high-value-added products such as the electronics industry, thus increasing outputs while ensuring a certain energy efficiency level. Finally, for 
high-income BRI countries, China's outward investment can raise the proportion of some new industries with low energy consumption and high output, such as the financial and information industries, to meet the needs of the domestic market in these countries while increasing their energy efficiencies.

The above research on this subject has given some conclusions and policy suggestions, however, it should be recognized that because of the limitations of the latest data, which is only up to 2018, whether the impact of the BRI on the energy efficiency of BRI countries will continue until today is not identified. Other than the DID method, other methods of policy simulation do exist, such as machine learning or Computable General Equilibrium (CGE) policy estimation, but they are usually used to study specific policy changes. The Belt and Road mainly includes five links covering policy communication, infrastructure connectivity, financial integration, unimpeded trade, and people-to-people connectivity, in addition to which many other factors may be involved, too. Therefore, it is impossible to calculate the macro policy behavior of participating in the Belt and Road based on other computing methods such as the general equilibrium model. In addition, if more data could be acquired to form a larger control group, the propensity score matching (PSM-DID) method can also be used to check the robustness of the results. If industry-specific energy efficiency data are available, we can further investigate the impact of joining the BRI on energy efficiency in different sectors of BRI countries.

The intended target audiences of this research are mainly policy makers on energy and the environment, economic administrators, and theoretical and empirical researchers on energy economics and international relations. Since the Belt and Road Initiative is a completely new thing, this study provides some inspiration for researchers in international economics, development economics, environmental economics, and related interdisciplinary disciplines and can inspire them to study the improvement of energy efficiency in developing countries from the perspective of international cooperation.

Author Contributions: Conceptualization, Y.W. and C.H.; methodology, X.S.; software, Y.W.; validation, Y.W. and C.H.; formal analysis, Y.W.; investigation, C.H.; resources, X.S.; data curation, C.H.; writing—original draft preparation, Y.W.; writing—review and editing, X.S.; visualization, C.H.; supervision, X.S.; project administration, X.S.; funding acquisition, Y.W. All authors have read and agreed to the published version of the manuscript.

Funding: This research was funded by the National Social Science Foundation of China, grant number 20CGJ019.

Institutional Review Board Statement: Not applicable.

Informed Consent Statement: Not applicable.

Data Availability Statement: Restrictions apply to the availability of the data. The data of the years for signing memorandum of understanding between BRI countries and China was obtained from Chinese government's Belt and Road Portal and are available at https:/ / www.yidaiyilu.gov. cn/gbjg/gbgk/77073.htm (accessed on 8 August 2021) with the permission of Chinese government's Belt and Road Portal. The data on energy efficiency was obtained from International Energy Agency (IEA) Statistics and are available at https: / / www.iea.org/data-and-statistics (accessed on 8 August 2021) with the permission of IEA. The data of share of FDI stock over GDP was obtained from World Investment Report and are available at https: / unctadstat.unctad.org/EN/ (accessed on 8 August 2021) with the permission of United Nations Conference on Trade and Development (UNCTAD). All the other variables' data was obtained from World Development Indicators and are available at https: / / databank.worldbank.org/source/world-development-indicators (accessed on 8 August 2021) with the permission of The World Bank.

Conflicts of Interest: The authors declare no conflict of interest. 


\section{References}

1. Tracy, E.F.; Shvarts, E.; Simonov, E.; Babenko, M. China's New Eurasian Ambitions: The Environmental Risks of the Silk Road Economic Belt. Eurasian Geogr. Econ. 2017, 58, 56-88. [CrossRef]

2. Rauf, A.; Liu, X.; Amin, W.; Ozturk, I.; Rehman, O.U.; Hafeez, M. Testing EKC Hypothesis with Energy and Sustainable Development Challenges: A Fresh Evidence from Belt and Road Initiative Economies. Environ. Sci. Pollut. Res. 2018, 25, 32066-32080. [CrossRef] [PubMed]

3. Ascensão, F.; Fahrig, L.; Clevenger, A.P.; Corlett, R.T.; Jaeger, J.A.G.; Laurance, W.F.; Pereira, H.M. Environmental Challenges for the Belt and Road Initiative. Nat. Sustain. 2018, 1, 206-209. [CrossRef]

4. Han, L.; Han, B.; Shi, X.; Su, B.; Lv, X.; Lei, X. Energy Efficiency Convergence across Countries in the Context of China's Belt and Road Initiative. Appl. Energy 2018, 213, 112-122. [CrossRef]

5. Qi, S.; Peng, H.; Zhang, X.; Tan, X. Is Energy Efficiency of Belt and Road Initiative Countries Catching up or Falling behind? Evidence from a Panel Quantile Regression Approach. Appl. Energy 2019, 253, 113581. [CrossRef]

6. Gu, A.; Zhou, X. Emission Reduction Effects of the Green Energy Investment Projects of China in Belt and Road Initiative Countries. Ecosyst. Health Sustain. 2020, 6, 1747947. [CrossRef]

7. Energy Efficiency Indicators-Data Product-IEA. Available online: https://www.iea.org/data-and-statistics/data-product/ energy-efficiency-indicators (accessed on 8 June 2021).

8. Stern, N. The Economics of Climate Change. Am. Econ. Rev. 2008, 98, 1-37. [CrossRef]

9. IPCC-Intergovernmental Panel on Climate Change. Available online: https://www.ipcc.ch/ (accessed on 24 August 2021).

10. Boyd, G.A.; Pang, J.X. Estimating the Linkage between Energy Efficiency and Productivity. Energy Policy 2000, 28, 289-296. [CrossRef]

11. Li, G.; Zakari, A.; Tawiah, V. Energy Resource Melioration and $\mathrm{CO}_{2}$ Emissions in China and Nigeria: Efficiency and Trade Perspectives. Resour. Policy 2020, 68, 101769. [CrossRef]

12. Liu, H.; Xi, Y.; Guo, J.; Li, X. Energy Embodied in the International Trade of China: An Energy Input-Output Analysis. Energy Policy 2010, 38, 3957-3964. [CrossRef]

13. State Information Center. One Belt and One Road Big Data Report; China's Commercial Press: Beijing, China, 2018. (In Chinese)

14. The Leading Group Office of the BRI. Jointly build the 'Belt and Road' Initiative: Progress, Contribution and Outlook. 2019. Available online: http://www.gov.cn/xinwen/2019-04/22/content_5385144.htm (accessed on 8 August 2021). (In Chinese)

15. Nasreen, S.; Anwar, S. Causal Relationship between Trade Openness, Economic Growth and Energy Consumption: A Panel Data Analysis of Asian Countries. Energy Policy 2014, 69, 82-91. [CrossRef]

16. Shahbaz, M.; Solarin, S.A.; Mahmood, H.; Arouri, M. Does Financial Development Reduce CO2 Emissions in Malaysian Economy? A Time Series Analysis. Econ. Model. 2013, 35, 145-152. [CrossRef]

17. Sohag, K.; Begum, R.A.; Syed Abdullah, S.M.; Jaafar, M. Dynamics of Energy Use, Technological Innovation, Economic Growth and Trade Openness in Malaysia. Energy 2015, 90, 1497-1507. [CrossRef]

18. Kyophilavong, P.; Shahbaz, M.; Anwar, S.; Masood, S. The Energy-Growth Nexus in Thailand: Does Trade Openness Boost up Energy Consumption? Renew. Sustain. Energy Rev. 2015, 46, 265-274. [CrossRef]

19. Koengkan, M. The Positive Impact of Trade Openness on Consumption of Energy: Fresh Evidence from Andean Community Countries. Energy 2018, 158, 936-943. [CrossRef]

20. Adom, P.K.; Kwakwa, P.A. Effects of Changing Trade Structure and Technical Characteristics of the Manufacturing Sector on Energy Intensity in Ghana. Renew. Sustain. Energy Rev. 2014, 35, 475-483. [CrossRef]

21. Sbia, R.; Shahbaz, M.; Hamdi, H. A Contribution of Foreign Direct Investment, Clean Energy, Trade Openness, Carbon Emissions and Economic Growth to Energy Demand in UAE. Econ. Model. 2014, 36, 191-197. [CrossRef]

22. Keho, Y. International Journal of Energy Economics and Policy Do Foreign Direct Investment and Trade Lead to Lower Energy Intensity? Evidence from Selected African Countries. Int. J. Energy Econ. Policy 2016, 6, 1-5.

23. Paramati, S.R.; Ummalla, M.; Apergis, N. The Effect of Foreign Direct Investment and Stock Market Growth on Clean Energy Use across a Panel of Emerging Market Economies. Energy Econ. 2016, 56, 29-41. [CrossRef]

24. Doytch, N.; Narayan, S. Does FDI Influence Renewable Energy Consumption? An Analysis of Sectoral FDI Impact on Renewable and Non-Renewable Industrial Energy Consumption. Energy Econ. 2016, 54, 291-301. [CrossRef]

25. Salim, R.; Yao, Y.; Chen, G.; Zhang, L. Can Foreign Direct Investment Harness Energy Consumption in China? A Time Series Investigation. Energy Econ. 2017, 66, 43-53. [CrossRef]

26. Sun, H.; Edziah, B.K.; Song, X.; Kporsu, A.K.; Taghizadeh-Hesary, F. Estimating Persistent and Transient Energy Efficiency in Belt and Road Countries: A Stochastic Frontier Analysis. Energies 2020, 13, 3837. [CrossRef]

27. Qi, S.Z.; Peng, H.R.; Zhang, Y.J. Energy Intensity Convergence in Belt and Road Initiative (BRI) Countries: What Role Does China-BRI Trade Play? J. Clean. Prod. 2019, 239, 118022. [CrossRef]

28. Huang, Z.; Zhang, H.; Duan, H. Nonlinear Globalization Threshold Effect of Energy Intensity Convergence in Belt and Road Countries. J. Clean. Prod. 2019, 237, 117750. [CrossRef]

29. Adedoyin, F.F.; Gumede, M.I.; Bekun, F.V.; Etokakpan, M.U.; Balsalobre-lorente, D. Modelling Coal Rent, Economic Growth and $\mathrm{CO}_{2}$ Emissions: Does Regulatory Quality Matter in BRICS Economies? Sci. Total Environ. 2020, 710, 136284. [CrossRef] [PubMed]

30. Liu, H.; Wang, Y.; Jiang, J.; Wu, P. How Green Is the "Belt and Road Initiative"?-Evidence from Chinese OFDI in the Energy Sector. Energy Policy 2020, 145, 111709. [CrossRef] 
31. Li, H.; Li, F.; Yu, X. China's Contributions to Global Green Energy and Low-Carbon Development: Empirical Evidence under the Belt and Road Framework. Energies 2018, 11, 1527. [CrossRef]

32. Anwar, M.A.; Nasreen, S.; Tiwari, A.K. Forestation, Renewable Energy and Environmental Quality: Empirical Evidence from Belt and Road Initiative Economies. J. Environ. Manag. 2021, 291, 112684. [CrossRef] [PubMed]

33. Wu, H.; Ren, S.; Yan, G.; Hao, Y. Does China's Outward Direct Investment Improve Green Total Factor Productivity in the “Belt and Road" Countries? Evidence from Dynamic Threshold Panel Model Analysis. J. Environ. Manag. 2020, 275, 111295. [CrossRef] [PubMed]

34. Wu, Y.; Chen, C.; Hu, C. Does the Belt and Road Initiative Increase the Carbon Emission Intensity of Participating Countries? China World Econ. 2021, 29, 1-25. [CrossRef]

35. Abbas, Q.; Nurunnabi, M.; Alfakhri, Y.; Khan, W.; Hussain, A.; Iqbal, W. The Role of Fixed Capital Formation, Renewable and Non-Renewable Energy in Economic Growth and Carbon Emission: A Case Study of Belt and Road Initiative Project. Environ. Sci. Pollut. Res. 2020, 27, 45476-45486. [CrossRef] [PubMed]

36. Wang, J.; Dong, X.; Dong, K. How Renewable Energy Reduces $\mathrm{CO}_{2}$ Emissions? Decoupling and Decomposition Analysis for 25 Countries along the Belt and Road. Appl. Econ. 2021, 53, 4597-4613. [CrossRef]

37. Cai, X.; Che, X.; Zhu, B.; Zhao, J.; Xie, R. Will Developing Countries Become Pollution Havens for Developed Countries? An Empirical Investigation in the Belt and Road. J. Clean. Prod. 2018, 198, 624-632. [CrossRef]

38. Liu, Z.; Zhang, H.; Zhang, Y.J.; Qin, C.X. How Does Income Inequality Affect Energy Efficiency? Empirical Evidence from 33 Belt and Road Initiative Countries. J. Clean. Prod. 2020, 269, 122421. [CrossRef]

39. Atta Mills, E.F.E.; Dong, J.; Yiling, L.; Baafi, M.A.; Li, B.; Zeng, K. Towards Sustainable Competitiveness: How Does Financial Development Affect Dynamic Energy Efficiency in Belt \& Road Economies? Sustain. Prod. Consum. 2021, 27, 587-601. [CrossRef]

40. Ahmad, M.; Jiang, P.; Majeed, A.; Raza, M.Y. Does Financial Development and Foreign Direct Investment Improve Environmental Quality? Evidence from Belt and Road Countries. Environ. Sci. Pollut. Res. 2020, 27, 23586-23601. [CrossRef] [PubMed]

41. Rauf, A.; Liu, X.; Amin, W.; Ozturk, I.; Rehman, O.U.; Sarwar, S. Energy and Ecological Sustainability: Challenges and Panoramas in Belt and Road Initiative Countries. Sustainability 2018, 10, 2743. [CrossRef]

42. Khan, A.; Chenggang, Y.; Hussain, J.; Kui, Z. Impact of Technological Innovation, Financial Development and Foreign Direct Investment on Renewable Energy, Non-Renewable Energy and the Environment in Belt \& Road Initiative Countries. Renew. Energy 2021, 171, 479-491. [CrossRef]

43. Akbar, M.W.; Yuelan, P.; Zia, Z.; Arshad, M.I. Role of Fiscal Policy in Energy Efficiency and CO2 Emission Nexus: An Investigation of Belt and Road Region. J. Public Aff. 2021, e2603. [CrossRef]

44. Akbar, U.; Popp, J.; Khan, H.; Khan, M.A.; Oláh, J. Energy Efficiency in Transportation along with the Belt and Road Countries. Energies 2020, 13, 2607. [CrossRef]

45. Yang, Z.; Wei, X. Analysis of the Total Factor Energy Efficiency and Its Influencing Factors of the Belt and Road Key Regions in China. Environ. Sci. Pollut. Res. 2018, 26, 4764-4776. [CrossRef]

46. Chen, Y.; Liu, S.; Wu, H.; Zhang, X.; Zhou, Q. How Can Belt and Road Countries Contribute to Glocal Low-Carbon Development? J. Clean. Prod. 2020, 256, 120717. [CrossRef]

47. Saud, S.; Chen, S.; Danish; Haseeb, A. Impact of Financial Development and Economic Growth on Environmental Quality: An Empirical Analysis from Belt and Road Initiative (BRI) Countries. Environ. Sci. Pollut. Res. 2018, 26, 2253-2269. [CrossRef] [PubMed]

48. Wu, Y.; Chen, C.; Hu, C. The Impacts of Trade Intensity with China on Carbon Emissions in Belt and Road Countries. J. Asia Pac. Econ. 2021. [CrossRef]

49. Wu, Y.; Shi, X.; Hu, C. Per Capita CO2 Emissions Divergence Influenced by Bilateral Trade with China under the Belt and Road Initiative. Sustain. Prod. Consum. 2021, 27, 1589-1601. [CrossRef]

50. Rauf, A.; Liu, X.; Amin, W.; Rehman, O.U.; Li, J.; Ahmad, F.; Victor Bekun, F. Does Sustainable Growth, Energy Consumption and Environment Challenges Matter for Belt and Road Initiative Feat? A Novel Empirical Investigation. J. Clean. Prod. 2020, $262,121344$. [CrossRef]

51. Ashenfelter, O. Estimating the Effect of Training Programs on Earnings. Rev. Econ. Stat. 1978, 60, 47. [CrossRef]

52. Wu, Y.; Chen, C. The Impact of China's Outward Foreign Direct Investment on Trade Intensity with Belt and Road Countries. Emerg. Mark. Financ. Trade 2021, 57, 1773-1792. [CrossRef]

53. Franco, S.; Mandla, V.R.; Ram Mohan Rao, K. Urbanization, Energy Consumption and Emissions in the Indian Context A Review. Renew. Sustain. Energy Rev. 2017, 71, 898-907. [CrossRef]

54. Li, K.; Fang, L.; He, L. How Urbanization Affects China's Energy Efficiency: A Spatial Econometric Analysis. J. Clean. Prod. 2018, 200, 1130-1141. [CrossRef]

55. Lv, Y.; Chen, W.; Cheng, J. Effects of Urbanization on Energy Efficiency in China: New Evidence from Short Run and Long Run Efficiency Models. Energy Policy 2020, 147, 111858. [CrossRef]

56. Grossman, G.; Krueger, A. Environmental Impacts of a North American Free Trade Agreement. Natl. Bur. Econ. Res. 1991. [CrossRef]

57. Li, K.; Lin, B. The Nonlinear Impacts of Industrial Structure on China's Energy Intensity. Energy 2014, 69, 258-265. [CrossRef]

58. Li, H.; Shi, J.F. Energy Efficiency Analysis on Chinese Industrial Sectors: An Improved Super-SBM Model with Undesirable Outputs. J. Clean. Prod. 2014, 65, 97-107. [CrossRef] 
59. Newell, R.G.; Jaffe, A.B.; Stavins, R.N. The Induced Innovation Hypothesis and Energy-Saving Technological Change. Q. J. Econ. 1999, 114, 941-975. [CrossRef]

60. Sener, S.; Karakas, A.T. The Effect of Economic Growth on Energy Efficiency: Evidence from High, Upper-Middle and LowerMiddle Income Countries. Procedia Comput. Sci. 2019, 158, 523-532. [CrossRef]

61. Wen, T.W.; Palanichamy, C.; Ramasamy, G. Energy Sustainability through Generation Scheduling. Int. J. Energy Econ. Policy 2020, 10, 147-157. [CrossRef]

62. Lund, H. Renewable Energy Strategies for Sustainable Development. Energy 2007, 32, 912-919. [CrossRef]

63. Xie, W.; Sheng, P.; Guo, X. Coal, Oil, or Clean Energy: Which Contributes Most to the Low Energy Efficiency in China? Util. Policy 2015, 35, 67-71. [CrossRef]

64. Fisher-Vanden, K.; Jefferson, G.H.; Jingkui, M.; Jianyi, X. Technology Development and Energy Productivity in China. Energy Econ. 2006, 28, 690-705. [CrossRef]

65. Xiao, H.; Ma, Z.; Zhang, P.; Liu, M. Study of the Impact of Energy Consumption Structure on Carbon Emission Intensity in China from the Perspective of Spatial Effects. Nat. Hazards 2018, 99, 1365-1380. [CrossRef]

66. Murshed, M. An Empirical Analysis of the Non-Linear Impacts of ICT-Trade Openness on Renewable Energy Transition, Energy Efficiency, Clean Cooking Fuel Access and Environmental Sustainability in South Asia. Environ. Sci. Pollut. Res. 2020, $27,36254-36281$. [CrossRef] [PubMed]

67. Wei, Z.; Han, B.; Pan, X.; Shahbaz, M.; Zafar, M.W. Effects of Diversified Openness Channels on the Total-Factor Energy Efficiency in China's Manufacturing Sub-Sectors: Evidence from Trade and FDI Spillovers. Energy Econ. 2020, 90, 104836. [CrossRef]

68. Pan, X.; Uddin, M.K.; Saima, U.; Jiao, Z.; Han, C. How Do Industrialization and Trade Openness Influence Energy Intensity? Evidence from a Path Model in Case of Bangladesh. Energy Policy 2019, 133, 110916. [CrossRef]

69. Liao, X.; Shi, X. (Roc) Public Appeal, Environmental Regulation and Green Investment: Evidence from China. Energy Policy 2018, 119, 554-562. [CrossRef]

70. Al-mulali, U.; Foon Tang, C. Investigating the Validity of Pollution Haven Hypothesis in the Gulf Cooperation Council (GCC) Countries. Energy Policy 2013, 60, 813-819. [CrossRef]

71. Shao, Q.; Wang, X.; Zhou, Q.; Balogh, L. Pollution Haven Hypothesis Revisited: A Comparison of the BRICS and MINT Countries Based on VECM Approach. J. Clean. Prod. 2019, 227, 724-738. [CrossRef]

72. Pan, X.; Guo, S.; Han, C.; Wang, M.; Song, J.; Liao, X. Influence of FDI Quality on Energy Efficiency in China Based on Seemingly Unrelated Regression Method. Energy 2020, 192, 116463. [CrossRef]

73. Chen, Z.; Paudel, K.P.; Zheng, R. Pollution Halo or Pollution Haven: Assessing the Role of Foreign Direct Investment on Energy Conservation and Emission Reduction. J. Environ. Plan. Manag. 2021, 1-46. [CrossRef]

74. Singhania, M.; Saini, N. Demystifying Pollution Haven Hypothesis: Role of FDI. J. Bus. Res. 2021, 123, 516-528. [CrossRef]

75. Sapkota, P.; Bastola, U. Foreign Direct Investment, Income, and Environmental Pollution in Developing Countries: Panel Data Analysis of Latin America. Energy Econ. 2017, 64, 206-212. [CrossRef]

76. Liu, Q.; Wang, S.; Zhang, W.; Zhan, D.; Li, J. Does Foreign Direct Investment Affect Environmental Pollution in China's Cities? A Spatial Econometric Perspective. Sci. Total Environ. 2018, 613-614, 521-529. [CrossRef]

77. Solarin, S.A.; Al-Mulali, U.; Musah, I.; Ozturk, I. Investigating the Pollution Haven. Energy 2017, 124, 706-719. [CrossRef]

78. Mielnik, O.; Goldemberg, J. Foreign Direct Investment and Decoupling between Energy and Gross Domestic Product in Developing Countries. Energy Policy 2002, 30, 87-89. [CrossRef]

79. Edziah, B.K.; Sun, H.; Anyigbah, E.; Li, L.; Edziah, B.K.; Sun, H.; Anyigbah, E.; Li, L. Human Capital and Energy Efficiency: Evidence from Developing Countries. Am. J. Ind. Bus. Manag. 2021, 11, 599-610. [CrossRef]

80. Bravo-Ortega, C.; de Gregorio, J. The Relative Richness of the Poor? Natural Resources, Human Capital, and Economic Growth. Lederman Maloney 2005. [CrossRef]

81. China's Belt and Road Portal. Available online: https://www.yidaiyilu.gov.cn/ (accessed on 8 August 2021).

82. UNCTAD (United Nations Conference on Trade and Development), World Investment Report, New York. Available online: https:// unctadstat.unctad.org/EN/ (accessed on 8 August 2021).

83. World Development Indicators I DataBank. Available online: https://databank.worldbank.org/source/world-developmentindicators (accessed on 8 August 2021).

84. Li, P.; Lu, Y.; Wang, J. Does Flattening Government Improve Economic Performance? Evidence from China. J. Dev. Econ. 2016, 123, 18-37. [CrossRef]

85. Topalova, P. Factor Immobility and Regional Impacts of Trade Liberalization: Evidence on Poverty from India. Am. Econ. J. Appl. Econ. 2010, 2, 1-41. [CrossRef] 